\title{
Peran Rupbasan sebagai Lembaga Pengelolaan Barang Sitaan Tindak Pidana Korupsi
}

\author{
Antok Kurniyawan dan Yola Nur Hasanah \\ Politeknik Ilmu Pemasyarakatan \\ Badan Pengembangan Sumber Daya Manusia \\ Kementerian Hukum dan HAM Republik Indonesia \\ antokakip@gmail.com
}

\begin{abstract}
Abstrak
Saat ini kasus korupsi menjadi salah satu tendensi kejahatan yang sedang meningkat. Peningkatan kuantitas dan kualitas benda sitaan negara tidak dapat dihindarkan. Rupbasan merupakan satu-satunya lembaga yang mempunyai wewenang untuk melakukan penyimpanan dan pengelolaan barang rampasan dan benda sitaan negara, dinilai belum dapat menjalankan tugas dan fungsinya sesuai amanat KUHAP. Rumusan masalah bagaimana peran rupbasan dalam pengelolaan aset sitaan hasil tindak pidana korupsi? dan bagaimana strategi yang dapat dilakukan melalui Revitalisasi guna memperbaiki kinerja Rupbasan dalam menjalankan tugas dan fungsinya secara optimal? Tujuan penelitian yaitu untuk menganalisa peran rupbasan dalam pengelolaan aset sitaan hasil tindak pidana korupsi. Kegunaan penelitian ini dapat memberikan kontribusi pandangan baru terhadap pengambilan kebijakan mengenai peran rupbasan dalam pengelolaan aset sitaan hasil korupsi guna mewujudkan birokrasi pengelolaan aset sitaan yang sesuai dengan undang-undang. Metode Penelitian menggunakan metode analisis yuridis empiris. Hasil penelitian menunjukan bahwa penyimpangan terhadap ketentuan pengelolaan aset sitaan sebagai akibat dari keterbatasan dan ketidaksesuaian proses kerja di Rupbasan, terhadap tuntutan tugas yang semakin berkembang. Kesimpulanya ialah pada hakikatnya Rupbasan memiliki kedudukan yang vital dalam pelaksanaan proses penyelesaian tindak pidana korupsi, namun karena keterbatasan dalam sarana, sumber daya manusia, dan ketimpangan dalam jenjang eselonering menjadi penghambat Rupbasan menjalankan tugas dan fungsinya. Melalui Revitalisasi dinilai sebagai opsi membangkitkan kembali muruah Rupbasan sebagai salah satu subsistem penegakan hukum.
\end{abstract}

Kata kunci: Revitalisasi, rupbasan, aset, hasil korupsi

\section{Rupbasan Roles as a Management of Corruption-Confiscated Goods}

\begin{abstract}
Nowadays corruption cases become one of the increasing crime tendencies. Increasing the quantity and quality of state confiscated objects is inevitable. Rupbasan is the only institution that has the authority to carry out the storage and management of state looted items and seized objects, which are considered unable to carry out their duties and functions in accordance with the mandate of the Criminal Procedure Code. Problem formulation how is
\end{abstract}


the role of rupbasan in the management of confiscated assets resulting from criminal acts of corruption? and what strategies can be carried out through Revitalization to improve the performance of Rupbasan in carrying out its tasks and functions optimally? The research objective is to analyze the role of rupbasan in the management of confiscated assets resulting from criminal acts of corruption. The usefulness of this research can contribute a new perspective on policy making regarding the role of rupbasan in the management of confiscated assets resulting from corruption in order to create a bureaucracy in the management of confiscated assets in accordance with the law. Research Methods using empirical juridical analysis methods. The results showed that the deviation from the provisions of confiscated asset management as a result of the limitations and mismatches of work processes in Rupbasan, to the growing demands of the task. The conclusion is that Rupbasan essentially has a vital position in the implementation of the process of resolving criminal acts of corruption, but due to limitations in facilities, human resources, and inequality in the echelonering level are obstacles to Rupbasan carrying out his duties and functions. Revitalization is seen as an option to revive Rupbasan muruah as one of the law enforcement subsystems.

Keywords: Revitalization, rupbasan, asset, result of corruption,

\section{Pendahuluan}

Negara Indonesia adalah negara hukum (Undang-Undang Dasar Negara Republik Indonesia Tahun 1945 Pasal 1 ayat (3)). Merupakan kalimat yang menjadi landasan konstitusional negara Indonesia untuk memberikan jaminan hak-hak bagi semua warga negara, serta mewajibkan seluruh warga negara untuk menjunjung tinggi pemerintahan dan hukum yang berlaku tanpa terkecuali (Jurnal Kajian Hukum, Wijaya, 2015: 205). Hukum yang bersifat mengikat berimplikasi tidak hanya warga negara namun juga petugas penegak hukum itu sendiri dalam bertindak sesuai ketentuan hukum yang berlaku. Undang-undang Nomor 8 Tahun 1981 Tentang Hukum Acara Pidana yang selanjutnya dikenal dengan Kitab Undang-undang Hukum Acara Pidana (KUHAP) sebagai pedoman petugas penegak hukum dalam penanganan dan penyelesaian perkara pidana dalam rangka melindungi Hak Asasi Manusia dan menjamin setiap warga negara bersamaan kedudukanya di depan hukum dan pemerintahan, serta wajib menjunjung tinggi hukum dan pemerinahan (penjelasan umum KUHAP).

Langkah penegakan hukum dalam pidana umum maupun pidana khusus tidak hanya difokuskan pada penanganan perkara semata, melainkan juga penanganan terhadap barang bukti sebagai bagian penting dalam menciptakan keadilan dan 
kepastian hukum itu sendiri. Prosedur penegakan hukum terhadap benda hasil tindak kejahatan sebagai barang bukti dalam proses pidana sering kali tidak selaras dengan tujuan dibentuknya hukum, yaitu memperoleh kebenaran yang sesungguhnya dan keadilan yang proporsional. Tidak dipungkiri dalam tindak pidana baik itu pidana umum ataupun pidana khusus sebagai contoh ialah tindak korupsi, dibutuhkan upaya paksa dalam bentuk penyitaan barang atau benda yang awalnya hak milik tersangka untuk dijadikan barang bukti dalam proses peradilan.

Pengaplikasian mengenai hukum acara telah diatur dalam KUHAP bahwa upaya pemaksaan dalam proses penyidikan termasuk didalamnya ialah proses penyitaan barang bukti tindak kejahatan telah dilegalkan secara hukum. Penyitaan didefinisikan sebagai cara, proses, perbuatan menyita atau pengambilan milik pribadi oleh pemerintah tanpa ganti rugi. Penyitaan ialah tindakan hukum berupa pengambilalihan kuasa untuk sementara waktu barang-barang dari kekuasaan seseorang atau kelompok untuk kepentingan penyidikan, penuntutan dan peradilan (Andi Hamzah, 1986: 122).. Penyitaan adalah serangkaian tindakan penyidik untuk mengambil alih atau menyimpan dibawah penguasaannya benda bergerak atau tidak bergerak, berwujud atau tidak berwujud untuk kepentingan pembuktian dalam penyidikan, penuntutan, dan peradilan (Undang-Undang Nomor 8 Tahun 1981 Tentang Hukum Acara Pidana Pasal 1). Benda yang dapat disita mencakup:benda yang dimiliki oleh terpidana secara keseluruhan maupun sebagian yang dipergunakan sendiri atau diperolehnya dari perbuatan kejahatan (Undang-Undang Nomor 8 Tahun 1981 Tentang Hukum Acara Pidana, 1981 Pasal 39):

a. benda yang dipergunakan untuk kejahatan;

b. benda dengan bantuan untuk perbuatan kejahatan;

c. benda dengan bantuan untuk menghalangi penyidikan;

d. benda yang akan digunakan untuk perbuatan kejahatan; dan

e. hak atas kebendaan

Demi kepastian, keadilan dan kebenaran hukum, barang sitaan yang disita disimpan di Rumah Penyimpanan Benda Sitaan Negara yang selanjutnya disebut RUPBASAN harus dapat dipertanggungjawabkan secara hukum dalam proses 
peradilan pidana yang menjunjung asas check and balance antar sub sistem dalam sistem peradilan pidana Indonesia. Tanggung jawab secara fisik barang sitaan terdapat pada Rupbasan ditujukan untuk memberikan perlindungan hak (milik barang) tersangka atau pihak ketiga (hak korban tindak pidana ataupun pihak lain yang masih terkait dengan tindak pidana yang dilakukan). Sementara tanggung jawab yuridis berada pada lembaga yang menangani sesuai tingkat pemeriksaan.

Ketentuan mengenai tata cara pengelolaan benda sitaan dan barang rampasan negara di Rupbasan telah diatur dalam Peraturan Menteri Hukum dan Hak Asasi Manusia Republik Indonesia Nomor 16 Tahun 2014 Tentang Tata Cara Pengelolaan Benda Sitaa Negara dan Barang Rampasan Negara Pada Rumah Penyimpanan Benda Sitaan Negara yang optimal diperlukan untuk menjaga keutuhan benda sitaan untuk keperluan pembuktian pada proses jalanya peradilan, tidak ada perubahan dan sama seperti pada saat dilakukannya tindak pidana oleh pelaku, serta terpeliharanya nilai benda sitaan yang bersangkutan.

Survei partisipasi publik menunjukan 98\% menilai bahwa Indonesia berada di level dengan tingkat korupsi tinggi dan 72\% korupsi karena adanya penegakan hukum yang lemah(Komisi Pemberantasan Korupsi, 19:2018). Data menunjukan bahwa indeks penegakan hukum oleh KPK mengalami peningkatan dari 62,27\% pada 2016 menjadi 71,03 \% pada 2018. Total nilai barang bukti yang berhasi disita oleh KPK mencapai 24,4 Miliyar yang terdiri dari benda bergerak maupun tak bergerak. Berkaitan dengan eskalasi penegakan hukum terhadap tindak korupsi tentunya memberi dampak berupa kenaikan volume benda sitaan negara yang begitu signifikan. Antara tahun 2016 sampai 2018 jumlah penyidikan oleh KPK mengalami kenaikan. Pada tahun 2016 jumlah penyidikan yang dijalankan sebanyak 99 kasus, sedangkan tahun 2018 sebanyak 199 kasus. Jumlah barang sitaan tentunya juga mengalami kenaikan. Namun, hal tersebut tidak diimbangi dengan penambahan kapasitas dari pihak Rupbasan baik dalam segi sarana prasarana dan segi SDM (Laporan Komisi Pemberantasan Korupsi, 2018: 73). Sementara pada peningkatan dari segi kuantitas pada Rupbasan Klas 1 Jakarta Barat di Tangerang terjadi pada tahun 2012. Pada bulan Maret 2012 total barang berjumlah 624 unit, meningkat tajam pada bulan April sejumlah 41270 unit 
(Direktorat Jenderal Pemasyarakatan, 2019). Hal itu sebagai implikasi bahwa benda sitaan sudah mulai harus dimasukan ke Rupbasan.

Salah satu berita online memberitakan Rumah Penyimpanan Barang Sitaan Negara (Rupbasan) Kelas 1 Jakarta Barat dan Tangerang menampung ribuan kendaraan bermotor yang menjadi barang sitaan negara. Uniknya, khusus untuk sepeda motor, kuncinya tetap terpasang. kata Kepala Administrasi dan Pemeliharaan Rupbasan, Ambarsari mengatakan dengan SDM terbatas, tidak sebading kendaraan yang ada. Jadi kunci dbiarkan menggantung di motornya ebih efisien saat waktunya pemanasan mesin. Tim pemeliharaan Rupbasan terdiri dari 13 orang untuk mengurus kendaraan sitaan dari kejaksaan negeri, kepolisian, dan Komisi Pemberantasan Korupsi (KPK) di kawasan Jakarta Barat dan Tangerang. Kendaraan-kendaran tersebut ditempatkan di beberapa tempat. Khusus untuk kendaraan sitaan KPK ditempatkan di gudang tertutup seluas 1.008 meter persegi. Sementara kendaraan lainnya yang terdiri dari sepeda motor berada di luar gudang. Sebagian besar ditempatkan di lahan terbuka dan beratap, sisanya hanya di lapangan tertutup terpal (Rima Wahyuningrum, 2018).

Berita lain muncul dari fokus.tempo.co menuliskan puluhan motor berkarat berjejer di halaman belakang Rupbasan Jakarta Selatan. Enam kendaraan yang terparkir di pelataran depan kantor juag punya nasib serupa, beberapa hampir menjadi barang rongsokan. Seluruh kendaraan menjadi barang bukti tindak kejahatan yang perkaranya masih dalam proses pemeriksaan (fokus.tempo.co, 2017). Hal tersebut menjadi permasalahan yang sampai saat ini belum juga ditemukan jalan keluarnya karena adanya keterbatasan dalam melakukan pengelolaan.

Namun pasca 30 tahun KUHAP operasionalisasi tugas dan fungsi Rupbasan tersebut sangat jauh dari harapan. Pada kenyataannya tidak semua kabupaten/kota di Indonesia memiliki Rupbasan. Demikian halnya dengan jumlah sumber daya manusia, infrastruktur pendukung dan anggaran untuk menyimpan dan memelihara benda sitaan masih minim. Sebagai rangkaian sub-sistem dalam sistem peradilan pidana, penyimpanan benda sitaan juga tidak luput dari permasalahan, antara lain meliputi permasalahan yang berkaitan dengan 
pelaksanaan tugas pokok dan fungsi Rupbasan sebagai tempat penyimpanan benda sitaan Negara, tata organisasi, dukungan biaya operasional, sumber daya manusia, dan operasional penanganan benda sitaan.

Penelitian sejenis sebelumnya pernah dilakukan oleh Lollong Manting dan Sudarwanto yang menghasilkan kesimpulan bahwa dalam melaksanakan fungsinya Rupbasan masih memiliki berbagai kendala seperti masih sangat kurang dari segi jumlah, status lahan yang sebagian besar belum milik sendiri, dan jumlah gudang yang masih sangat jauh dari memadai dan standar yang ada. Hal ini menyebabkan pengelolaan yang belum optimal (Jurnal Pendidikan, Hukum dan Bisnis, Lollong Manting : 2019). Sedangkan penelitian Setyadi mengungkapkan pentingnya Rupbasan sebagai penjamin keberadaan dan keamanan benda sitaan sebagai bukti dalam proses pengadilan, juga karena nilainya yang sangat berharga, baik nilainya bagi perkara, maupun nilai nominalnya, khususnya dalam perkara besar seperti korupsi (Jurnal Kajian Hukum, Setyadi, 2016: 211). Dalam penelitian Hibnu, Budiono, dan Pranoto memberikan saran dalam upaya pengoptimalisasi pemanfaatan aset benda sitaan Negara maka dilakukan dengan lebih mengintensifkan koordinasi dan kerjasama Rupbasan dengan Kementerian Keuangan melalui Direktorat Jenderal Kekayaan Negara ( Journal of Information Technology and Computer Science, Nugroho et. al., 2017). Dalam penelitian ini akan mendekan keadaan Rupbasan pada saat ini, hambatan-hambatan baik dalam segi ketentuan perundang-undangan, kebijakan maupun dalam segi pelaksanaanya. Pada penelitian ini juga terkandung salah satu gambaran solusi untuk menjawab tantangan dan hambatan yang berkaitan dengan tugas dan fungsi Rupbasan.

Berangkat dari ketentuan perundang-undangan yang dipadukan dengan situasi dan kondisi di lapangan maka terdapat dua masalah yang peneliti temukan yaitu:

a. Bagaimana peran Rupbasan dalam pengelolaan barang hasil sitaan tindak pidana korupsi ? 
b. Bagaimana strategi yang dapat dilakukan melalui Revitalisasi guna memperbaiki kinerja Rupbasan dalam menjalankan tugas dan fungsinya secara optimal?

Penelitian diharapkan akan memberikan kontribusi dalam mengambil kebijakan strategis terutama dalam bidang hukum yang diarahkan pada perbaikan organisasi guna mewujudkan birokrasi pengelolaan aset sitaan yang sesuai dengan ketentuan undang-undang. Salah satu solusi yang bisa dilakukan ialah melakukan revitalisasi dan restrukturisasi pada Rupbasan.

Penelitian ini menggunakan metode analisis yuridis empiris. Penelitian dilakukan dengan memadukan bahan-bahan sumber hukum berupa peraturan perundang-udangan dengan mengobservasi peristiwa empiris yang terjadi. Sumber hukum yang digunakan dalam penelitian ini antara lain :

a. Undang-Undang Nomor 8 Tahun 1981 Tentang Hukum Acara Pidana

b. Peraturan Pemerintah Nomor 27 Tahun 1983 Tentang Pelaksanaan KUHAP

c. Peraturan Menteri Hukum dan HAM Nomor 16 Tahun 2014 Tentang Tata Cara Pengelolaan Benda Sitaan Negara dan Barang Rampasan Negara pada Rupbasan, serta peraturan lain yang berkaiatan dengan tugas dan fungsi Rupbasan.

Sementara analisis empiris dilakukan dengan mengobservasi secara langsung terkait tugas dan fungsi Rupbasan, melakukan wawancara kepada Kepala Sub Seksi Administrasi dan Pemeliharaan serta Kepala Sub Seksi Pengamanan dan Pengelolaan Rupbasan pada Rupbasan Kelas I Jakarta Barat di Tangerang.

\section{Pembahasan}

\section{A. Eksistensi Rupbasan dalam Kaitanya dengan Kedudukan, Tugas dan Fungsi Rupbasan}

Sesuai amanat undang-undang, Rupbasan merupakan satu-satunya lembaga yang memiliki tugas dan fungsi untuk melakukan penyimpanan dan pengelolaan benda sitaan yang dipegunakan sebagai barang bukti pada proses peradilan, termasuk barang yang dinyatakan dirampas oleh negara berdasarkan putusan 
hakim. Benda dengan status sitaan negara dilarang untuk dipergunakan oleh siapapun tanpa dasar hukum yang jelas.

Ide dasar mengenai amanah undang-undang untuk membentuk Rupbasan ialah untuk tetap menjaga terpeliharanya keselamatan dan keamanan benda sitaan negara dalam satu kesatuan unit (Peraturan Pemerintah Nomor 27 Tahun 1983 Tentang Pelaksanaan Kitab Undang Undang Hukum Acara Pidana Pasal 27). Kebijakan ini akan memudahkan dalam pemeliharaan dan pengawasan serta ada penanggung jawab tertentu secara fisik terhadap benda sitaan tersebut untuk menjaga benda sitaan tetap utuh dan tidak mengalami penyusutan nilai. Keutuhan benda sitaan sangat penting tidak hanya untuk keperluan pembuktian saat proses peradilan, melainkan juga untuk melindungi hak milik individu, baik tersangka maupun hak milik pihak pihak lain yang terkait dengan tindak pidana.

Mempertimbangkan bahwa untuk mewujudkan terbentuknya Rupbasan memerlukan waktu yang cukup lama dan anggaran yang besar, maka sebelum terbentuknya Rupbasan berdasar Peraturan Pemerintah, penyimpanan benda sitaan tersebut dapat dilakukan di kantor Kepolisian Negara Republik Indonesia, di kantor Kejaksaan Negeri, di kantor Pengadilan Negeri dan tempat-tempat lain sesuai dengan ketentuan dalam KUHAP (Peraturan Pemerintah Nomor 27 Tahun 1983 pasal 39). Hal serupa juga tertulis Peraturan Bersama yang menyatakan bahwa benda sitaan dan barang rampasan dapat disimpan di luar rupbasan (Peraturan Bersama Kepala Kepolisian Republik Indonesia, Jaksa Agung, Komisi Pemberantasan Korupsi, Menteri Hukum dan Hak Asasi Manusia, Mahkamah Agung, Menteri Keuanagan Tentang Sinkronisasi Ketatalaksanaan Sistem Pengelolaan Benda Sitaan Negara dan Baran Tahun 2012 pasal 2 ayat (1)). Meskipun tempat penyimpanan tidak di Rupbasan, Kepala Rupbasan tetap mempunyai wewenang penuh dalam mengambil keputusan lokasi dimana benda sitaan akan di tempatkan (Peraturan Menteri Hukum dan Hak Asasi Manusia Republik Indonesia Nomor 16 Tahun 2014 Tentang Tata Cara Pengelolaan Benda Sitaan Negara dan Barang Rampasan Negara pada Rumah Penyimpanan Benda Sitaan Negara Pasal 2 ayat (2)). 
Tugas dan fungsi Rupbasan ialah menyimpan dan mengelola benda sitaan Negara (Basan) dan Barang Rampasan Negara (Baran) yang merupakan suatu rangkaian kegiatan dimulai sejak proses penerimaan sampai pada pengeluaran Basan dan Baran. Rangkaian kegiatan tersebut meliputi (Peraturan Menteri Hukum dan Hak Asasi Manusia Republik Indonesia Nomor 16 Tahun 2014 Tentang Tata Cara Pengelolaan Benda Sitaan Negara dan Barang Rampasan Negara pada Rumah Penyimpanan Benda Sitaan Negara pasal 2 ayat (2)):

1. Penerimaan, penelitian, penilaian, pendaftaran dan penyimpanan Basan dan Baran;

2. Pemeliharaan Basan dan Baran;

3. Pemutasian Basan dan Baran;

4. Pengeluaran dan Penghapusan Basan dan Baran; dan

5. Penyelamatan dan Pengamanan Basan dan Baran .

Eksistensi Rupbasan terutama dalam kaitanya melakukan pengelolaan menjadi sangat vital, mengingat tugas dan fungsinya sangat berpengaruh dan turut serta dalam penegakan hukum, melalui pengelolaan barang bukti untuk kepentingan proses pemeriksaan dan proses pengambilan keputusan hakim dalam menjatuhkan pidana yang dianggap adil dan benar menurut kacamata hukum yang berlaku di Indonesia.

\section{B. Permasalahan dan Hambatan}

\section{Perbandingan jumlah Unit Pelaksana Teknis Rupbasan}

Ketentuan peraturan perundang-undangan menghendaki bahwa unit pelaksana teknis Rupbasan di bentuk di setiap ibu kota Kabupaten/ Kotamadya (Peraturan Pemerintah Nomor 27 Tahun 1983 pasal 26 ayat (1)). Namun fakta menunjukan sampai Tahun 2019 unit pelaksana teknis Rupbasan hanya terdapat 63 unit yang tersebar di 32 provinsi (Sistem Database Pemasyarakatan, 2019). Provinsi Kalimantan Barat dan Provinsi Sulawesi barat sampai saat ini belum mempunyai unit pelaksana teknis Rupbasan. Seyogianya jumlah unit pelaksana teknis Rupbasan mengikuti jumlah Kabupaten / Kota Se-Indonesia yaitu kurang lebih 530. 
Tabel 1. Jumlah Unit Kantor Rupbasan

\begin{tabular}{|c|c|}
\hline $\begin{array}{c}\text { Unit Pelaksana Teknis } \\
\text { Rupbasan }\end{array}$ & Jumlah \\
\hline Kelas I & 35 \\
\hline Kelas II & 28 \\
\hline Jumlah & $\mathbf{6 3}$ \\
\hline
\end{tabular}

Sumber : Sistem Database Pemasyarakatan, smslap.ditjenpas, diakses 17 Oktober 2019

Tabel 2. Jumlah Kantor Kepolisian Resort

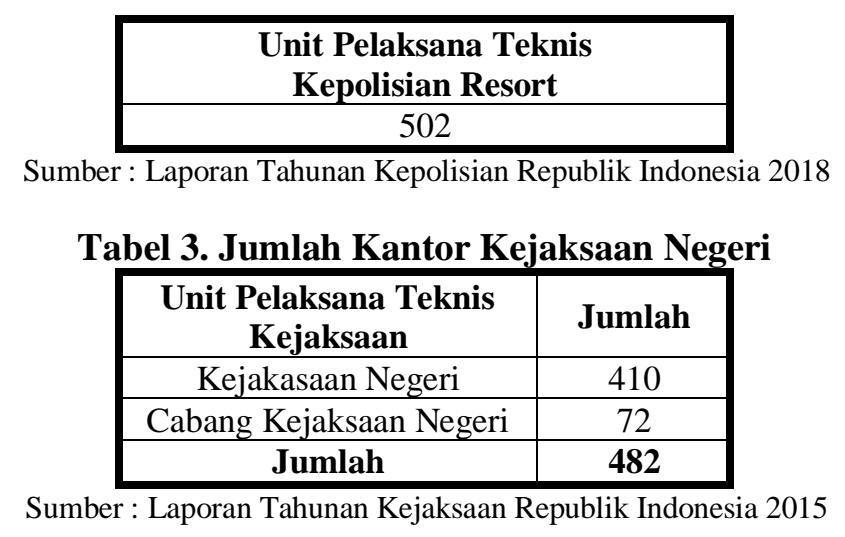

Melalui data tersebut, terlihat beban tanggung jawab yang sangat tidak seimbang. Rupbasan harus mampu menampung benda siataan dari unit pelaksana teknis yang jumlah perbandinganya sekitar $1: 9$.

\section{Sarana dan prasarana yang terbatas}

Keterbatasan sarana dan prasarana yang menyangkut gedung/gudang serta anggaran dalam mendukung pelaksanaan fungsi Rupbasan. Kesiapan Kementerian Hukum dan HAM utk membangun Rupbasan di seluruh Kabupaten/Kota Sesuai amanat KUHAP sampai saat ini, masih belum terlaksana. Meski secara yuridis penyimpanan benda sitaan negara adalah di Rumah Penyimpanan Benda Sitaan Negara (RUPBASAN), namun keberadaan dan jumlah Rupbasan yang tidak sebanding dengan jumlah lembaga penegak hukum yang melakukan penyitaan dan yang bertanggung jawab secara yuridis terhadap benda sitaan dalam hal ini Kepolisian, Kejaksaan dan Pengadilan.

Berdasarkan data ada 63 unit Rupbasan, belum ada satupun Rupbasan yang memenuhi standar ideal sebagai suatu Rupbasan yang semestinya memiliki 5 jenis gudang yaitu gudang umum tertutup, gudang umum terbuka, 
gudang berharga, gudang berbahaya dan kandang untuk hewan dan tumbuhan serta sarana utilitas dan prasarana lingkungan. Mayoritas Rupbasan hanya memiliki 2 , atau 3 jenis gudang saja, bahkan ada kantor Rupbasan yang tidak memiliki gudang. Hal ini menjadi permasalahan didalam penempatan benda sitaan di dalam lingkungan kantor Rupbasan (Laporan Tahunan Direktorat Jendral Pemasyarakatan : 2017).

Tabel 4. Status kepemilikan lahan Rupbasan (Jenderal Pemasyarakatan, 2017)

\begin{tabular}{|l|c|l|c|}
\hline \multicolumn{4}{|c|}{ Status kepemilikan lahan Rupbasan } \\
\hline Milik sendiri & 27 & Numpang di rutan & 1 \\
\hline Hak pakai & 3 & Milik lapas & 5 \\
\hline Milik kanwil & 9 & Ex bapas & 1 \\
\hline Ex lapas & 3 & Hak guna pakai lp & 1 \\
\hline Ex rumah dinas & 2 & Ex gedung bhp & 2 \\
\hline Hibah pemerintah & 1 & Ex gd agrarian & 1 \\
\hline Ngontrak rumah & 2 & Milik rutan & 1 \\
\hline Hibah hak pakai & 1 & Milik pemda & 1 \\
\hline Ex puskesmas pemda & 1 & Hak pakai tanah ngara & 1 \\
\hline \multicolumn{2}{|c|}{ Sumber : Laporan Tahunan Direktorat Jenderal Pemasyarakatan 2017 }
\end{tabular}

Tabel 5. Daftar Kepemilikan Gudang oleh Rupbasan

\begin{tabular}{|c|c|}
\hline Kepemilikan Gudang & Unit \\
\hline 5 gudang & - \\
\hline 4 gudang & 19 \\
\hline 3 gudang & 21 \\
\hline 2 gudang & 17 \\
\hline 1 gudang & 4 \\
\hline Tanpa Gudang & 2 \\
\hline Jumlah & $\mathbf{6 3}$ \\
\hline
\end{tabular}

Status lahan yang sebagian besar belum milik sendiri, dan jumlah gudang yang masih sangat jauh dari memadai dan standar yang ada maka implementasi terhadap ketentuan yang mengatur tentang Rupbasan dalam rangka pengelolaan semua benda yang disita oleh negara belum dapat dilaksanakan secara maksimal.

\section{Jenjang Eselon yang masih rendah}

Salah satu aspek yang menyebabkan belum terlaksananya tugas dan fungsi Rupbasan secara optimal pada saat ini dapat dilihat dari adanya 
kesenjangan golongan unit pelaksana teknis Rupbasan dengan unit pelaksana teknis penegak hukum yang terkait dalam penyelesaian peradilan pidana yaitu kepolisian dan kejaksaan yang sudah berada digolongan eselon III ditingkat unit pelaksana teknis pada kabupaten dan kota madya. Sedangkan Kepala Rupbasan sebagai pejabat tertinggi di rupbasan hanya berada pada golongan eselon IV. Hal tersebut mengakibatkan Kepala Rupbasan tidak memiliki kewenangan dan pegawai yang cukup dibandingkan dengan tanggung jawab yang diembannya. Perbedaan golongan eselon ini dapat mengganggu proses singkronisasi kerja sama antara Rupbasan dengan instansi penegak hukum lain.

\section{Biaya Pemeliharaan}

Beban pemliharaan benda sitaan yang ditempatkan dalam Rupbasan tidak bisa dibilang ringan. Benda sitaan dengan kategori mewah, tentunya memerlukan pemeliharaan yang khusus supaya nilai barang tersebut tidak menyusut. Dalam wawancara dengan fokus.tempo.co, Kepala Rupbasan Jakarta Selatan menyatakan dana operasional hanya Rp 20 juta per tahun (Ferdiyanto, 2017). Jumlah tersebut pastinya tidak akan mencukupi untuk pemeliharaan yang bersifat khusus dan darurat.

\section{Kemampuan Sumber Daya Manusia Terbatas}

Aspek pemenuhan kualitas dan kuatitas sumber daya manusia (petugas Rupbasan), termasuk di dalamnya pemenuhan dan ketersediaan terhadap anggaran demi terlaksanya tugas dan fungsi petugas sangat penting diperhatikan. Terkait dengan sumber daya manusia, sampai saat ini petugas yang mempunyai keahlian spesifik dalam melakukan penilaian terhadap benda sitaan dan barang rampasan belum memadai baik kuantitas maupun kualitas, bahkan dapat dikatakan masih banyak Rupbasan belum memiliki sama sekali tenaga ahli peneliti dan penilai. Ketersediaan sumber daya manusia (petugas) yang memiliki keahlian sebagai peneliti dan penilai yang terbatas, maka Rupbasan hanya menempatkan petugas (staff umum) untuk melakukan penelitian dan penilaian secara umum. 


\section{Solusi melalui Revitalisasi Rupbasan}

Revitalisasi menjadi salah satu opsi solusi yang dapat diambil dalam menangani berbagai permasalahan yang ada pada Rupbasan. Revitalisasi merupakan suatu proses maupun perbuatan menghidupkan atau meggiatkan kembali (Sugono, 2008:560) . Revitalisasi bisa didefinisikan sebagai upaya untuk menjadikan sesuatu atau perbuatan menjadi vital. Revitalisasi Rupbasan merupakan suatu upaya mengoptimalisasi penyelenggaraan seluruh proses yang menyangkut tugas dan fungsi Rupbasan untuk menyimpan dan mengelola benda sitaan dan barang rampasan serta sebagai perlindungan atas hak kepemilikan terhadap barang bukti.

Untuk melaksanakan revitalisasi perlu adanya keterlibatan stakeholder lain seperti penegak hukum dan pemerintah selaku pemangku kebijakan dan pengambil keputusan dalam menciptakan birokrasi. Revitalisasi dapat dijalankan menjadi beberapa langkah yaitu :

\section{Peningkatan Jenjang Eselon Secara Kelembagaan}

Struktur organisasi harus dikembangkan dengan memaksimalkan jumlah serta golongan pejabat struktural dan pegawai melalui peningkatan eselonering dengan memperhatikan :

a. Volume pekerjaan yang semakin meningkat

b. Kesenjangan kesetaraan eselonering dengan aparat penegak hukum lainnya.

c. Kompetensi pegawai Rupbasan yang belum maksimal

Berdasarkan gambaran tersebut peningkatan eselonering dari eselon IV menjadi eselon III sangat diperlukan dengan harapan :

a. Terdapat penambahan jabatan struktural dan membuka peluang adanya jabatan fungsional tertentu apabila jumlah pegawai memadai di setiap Rupbasan.

b. Instansi penegak hukum terkait segera merespon dan memperhatikan koordinasi yang dilakukan oleh pihak Rupbasan apabila terdapat kesetaraan eselonering

c. Terselenggaranya kegiatan bimbingan teknis. 


\section{Pengangkatan petugas jabatan fungsional tertentu}

Sebagaimana diketahui bahwa salah satu tujuan terbentuk Rupbasan ialah melakukan pengelolaan berupa pemeliharaan benda sitaan dengan tujuan untuk tetap menjaga nilai barang tersebut. Oleh karena itu pada saat benda sitaan diterima oleh Rupbasan, Tim Peneliti dan Petugas Penilai akan melakukan penilaian. Tim Peneliti ialah tim yang yang ditunjuk oleh Kepala Rupbasan terdiri dari petugas Rupbasan yang memiliki keahlian tertentu untuk melakukan pemeriksaan, penelitian, dan pengidentifikasian atas Basan dan Baran (Peraturan Menteri Hukum dan Hak Asasi Manusia Republik Indonesia Nomor 16 Tahun 2014 Pasal 1) . Petugas Penilai adalah petugas Rupbasan yang memiliki keahlian menaksir dan menentukan mutu dan nilai Basan dan Baran yang bersertifikat ditunjuk oleh Kepala Rupbasan (Peraturan Menteri Hukum dan Hak Asasi Manusia Republik Indonesia Nomor 16 Tahun 2014 Pasal 7). Dalam hal Rupbasan belum memiliki Petugas Penilai, Kepala Rupbasan dapat menunjuk seseorang yang memiliki sertifikat keahlian untuk menaksir mutu dan nilai Basan (Undang-Undang Republik Indonesia Nomor 5 Tentang Aparatur Sipil Negara Tahun 2014).

Saat ini jabatan tim peniliti dan penilai masih berada pada susunan jabatan struktural dibawah Sub Seksi Administrasi dan Pemeliharaan. Apabila dilakukan analisis jabatan menggunakan pendekatan beban kerja maka Tim Peneliti dan Petugas penilai lebih tepat masuk kedalam jabatan fungsional tertentu. Jabatan Fungsional Aparatur Sipil Negara adalah sekelompok jabatan yang berisi fungsi dan tugas berkaitan dengan pelayanan fungsional yang berdasarkan pada keahlian dan keterampilan tertentu (Laporan Badan Pusat Statistilk, 2018 : 79). Jabatan Fungsional Tertentu didasarakan dengan kriteria sebagai berikut:

a. Mempunyai metodologi, teknik analisis, teknik dan prosedur kerja yang didasarkan atas disiplin ilmu pengetahuan dan pelatihan teknis tertentu dengan sertifikasi;

b. Memiliki etika profesi yang ditetapkan oleh organisasi profesi;

c. Dapat disusun dalam suatu jenjang jabatan berdasarkan: 
1) tingkat keahlian

2) tingkat keterampilan

d. Pelaksanaan tugas bersifat mandiri (diperlukan dalam pelaksanaan tugas pokok dan fungsi) Jabatan Fungsional Tertentu organisasi.

Penempatan Tim Peneliti dan Petugas Penilai berada pada jabatan fungsional tertentu dalam rumpun jabatan pengawas kualitas dan kemananan, berddampak pada sistem remunerasi akan berdasarkan pada merit system, yaitu penetapan besarnya remunerasi berbasis kinerja, bobot pekerjaan dan grade dengan tujuan untuk meningkatkan prestasi kerja (Journal of Information Technology and Computer Science, Syaputra, 2019 : 69-74).

\section{Perubahan terhadap Surat Edaran Mahkamah Agung Nomor 01} Tahun 2011 tentang Perubahan Surat Edaran Mahkamah Agung Nomor 2 Tahun 2010 tentang Penyampaian Salinan dan Petikan

\section{Putusan}

Sebagai salah satu subsistem dalam sistem peradilan pidana di Indonesia, Rupbasan harus melakukan sinkronisasi dengan penegak hukum lainya, terkait tugas dan fungsi yang menjadi tanggung jawabnya. Untuk itu telah dibuat Peraturan bersama, Sistem Pengelolaan, Benda Sitaan, Barang Rampasan Negara, dan Ketatalaksanaan yang disepakati oleh Kepala Polisi, Jaksa Agung, Komisi Pemberantasan Korupsi, Menteri Hukum dan HAM, Mahkamah Agung, dan Menteri Keuangan (Busroh, 2016 :56).

Dalam hal perkara telah memperoleh kekuatan hukum tetap, Jaksa wajib menyampaikan petikan putusan pengadilan kepada Rupbasan. Namun berdasarkan hasil penelitian empiris di Rupbasan Kelas I Jakarata Barat, salah satu permasalahan yang ada ialah Rupbasan mengalami kesulitan untuk melacak dokumen putusan pengadilan. Pihak Kejaksaan selaku eksekutor tidak selalu memberikan salinan putusan pengadilan, sehingga Rupbasan yang hanya mempunyai kewenangan perlindungan fisik tidak dapat melakukan pengelolaan lebih lanjut yaitu berupa pemutasian. Hal tersebut berdampak pada menumpuknya barang di Rupbasan, tanpa ada kewenangan 
apapun dari Kepala Rupbasan dalam melakukan tindakan lebih lanjut atas barang tersebut.

Salah satu langkah yang yang bisa dilakukan ialah melakukan perubahan terhadap Surat Edaran Mahakamah Agung Nomor 01 Tahun 2011 tentang Perubahan Surat Edaran Mahkamah Agung Nomor 2 Tahun 2010 tentang Penyampaian Salinan saan Petikan Putusan. Salah satu poin surat edaran tersebut ialah petikan putusan perkara hanya diberikan kepada terdakwa, penuntut umum, dan Rumah Tahanan Negara atau Lembaga Pemasyarakatan setelah putusan diucapkan (Surat Edaran Ketua Mahkamah Agung Republik Indonesia Nomor 01 Tahun 2011 tentang Perubahan Surat Edaran Mahkamah Agung Nomor 2 Tahun 2010 tentang Penyampaian Salinan dan Petikan Putusan, 2011).

Sebagai salah satu perbaikan birokrasi maka Rupbasan bisa di tambahkan sebagai salah satu unit yang berhak menerima salinan putusan atas benda sitaan, sehingga langkah pengelolaan benda siataan lebih lanjut dapat diambil oleh Kepala Rupbasan.

\section{Penutup}

\section{A. Kesimpulan}

Rumah Penyimpanan Benda Sitaan Negara yang selanjutnya disebut Rupbasan merupakan satu-satunya lembaga yang memiliki tugas dan fungsi untuk melakukan penyimpanan benda sitaan Negara menurut KUHAP. Kesimpulan yang dapat diambil yaitu :

1. Secara kelembagaan Rupbasan memiliki kedudukan yang vital dalam pelaksanaan proses penyelesaian tindak pidana karena tugas Rupbasan yang terkait dengan keamanan dan keselamatan barang bukti tindak kejahatan akan menjadi salah satu aspek penentu pengambilan keputusan oleh hakim, namun hal tersebut belum mendorong eksistensi Rupbasan sebagaimana amanat undang-undang. Rupbasan dianggap lembaga penitipan barang semata, meskipun masih terdapat beberapa kendala yang dihadapi Rupbasan dalam pelaksanaan fungsi yang semestinya. Keterbatasan dalam sarana prasarana, 
sumber daya manusia, dan ketimpangan dalam jenjang eselonering menjadi penghambat Rupbasan dalam menjalankan tugas dan fungsinya.

2. Melalui Revitalisasi sebagai opsi dalam membangkitkan kembali Rupbasan sebagai salah satu instansi penegak hukum. Peningkatan jenjang eselon kelembagaan, pembentukan jabatan fungsional tertentu, dan perubahan terhadap Surat Edaran Mahkamah Agung Nomor 1 Tahun 2011 Tentang Perubahan Surat Edaran Mahkamah Agung Nomor 2 Tahun 2010 tentang Penyampaian Salinan dan Petikan Putusan menjadi salah satu opsi strategi yang mungkin untuk dilakukan. Tujuan secara umum yaitu terwujudnya keadilan, kebenaran dan kepastian hukum itu sendiri. Sementara tujuan khusus yang akan dicapai ialah mempertahankan kondisi benda sitaan supaya tidak rusak, tidak disalahgunakan dan tetap memiliki nilai aset yang tinggi, terutama benda sitaan hasil korupsi.

\section{B. Saran}

Semangat pemberantasan korupsi memang tidak boleh dihilangkan. Berbagai gejolak penolakan terhadap revisi Undang-undang tentang Komisi Pemberantasan Korupsi yang terjadi beberapa waktu lalu seolah menjadi bukti nyata semangat pemberantasan korupsi masih tetap terjaga dan cenderung meningkat. Selain demonstrasi yang dilakukan, salah satu langkah nyata dalam rangka melawan tindak korupsi ialah adanya penelitian, analisis dan diskusi terkait isu tentang korupsi. Kaitanya dengan hal tersebut maka diperlukan langkah lebih lanjut berupa :

1. Perhatian khusus dari Kementerian Hukum dan HAM dalam melakukan perbaikan Rupbasan dan pembentukan Peraturan Menteri sebagai salah satu payung hukum untuk Rupbasan dalam melakukan langkah lebih lanjut terhadap benda sitaan yang telah berada dalam Rupbasan dalam jangka waktu yang cukup lama.

2. Membentuk legislasi minimal berada dalam level Peraturan Pemerintah dan bukan Peraturan Presiden. Selain itu, Rupbasan perlu mempertimbangkan penempatan pengaturan secara lebih rinci dalam Rancangan KUHAP yang 
akan dibahas oleh Pemerintah dan DPR atau sesegera mungkin mendorong rencana RUU pengelolaan aset kejahatan yang komprehensif.

3. Mekanisme hubungan perlu ditata kembali karena itu dibutuhkan pengaturan selevel Peraturan Pemerintah sebagai peraturan transisi sebelum memastikan Rancangan KUHAP dalam rangka revitalisasi Rupbasan serta memberikan pengaturan yang memadai mengenai Rupbasan. Diperlukan pemilahan secara tegas antara yang memberikan ijin, yang melakukan penyitaan dan perampasan, dan yang melakukan pemeliharaan

4. Tema pemberantasan korupsi yang sangat menarik dan aktual perlu untuk dibahas dan dianalisis lebih lanjut dalam suatu forum khusus yang dihadiri oleh berbagai elemen baik dari elemen pemerintah, penegak hukum, akademisi, praktisi, masyarakat umum dan tentunya generasi muda, sebagai salah satu langkah untuk mencari jalan keluar dan memberikan masukan dalam menentukan strategi pemberantasan korupsi yang efektif dan efisien.

5. Penelitian yang mengangkat tema pemulihan dan pengelolaan aset sitaan hasil tindak pidana korupsi dalam kaitanya membentuk sistem anti korupsi yang optimal tentunya membutuhkan pendalaman literatur dan penelitian lapangan lebih mendalam serta diperlukan pembahasan dari perspektif yang berbeda supaya menghasilakan solusi yang dapat diterima oleh semua stakeholder.

\section{Daftar Pustaka}

Badan Pusat Statistilk. Tingkat Kejahatan Narkotika. Jakarta, Republik Indonesia, 2018.

Busroh, F. F. Teknik Perundang-Undangan suatu Pengantar. Jakarata, Republik Indonesia: Cintya Press, 2016.

Hamzah, A. Pengusutan Perkara Melalui Sarana Teknik dan Sarana Hukum. Jakarta: Ghalia Indonesia, 1986.

Kejaksaan Republik Indonesia. Laporan Tahunan Kejaksaan Republik Indonesia 2015. Jakarta: Kejaksaan Agung Republik Indonesia, 2015. 
Kepolisisan Republik Indonesia. Laporan Tahunan Kepolisisan Republik Indonesia 2018. Jakarta : Kepolisian Republik Indonesia, 2015.

Komisi Pemberantasan Korupsi. Laporan Tahunan Komisi Pemberantasan Korupsi Tahun 2018. Jakarta: Komisi Pemberantasan Korupsi, 2018.

Manting, Lollong. “Analisis Pengelolaan Benda Sitaan dan Barang Rampasan Negara dalam Rumah Penyimpanan Benda Sitaan dan Barang Rampasan Negara (Rupbasan).” Jurnal Pendidikan, Hukum dan Bisnis Vol. 5, no. 1, 2019.

Nugroho et. al., H. Optimalisasi Pemanfaatan Aset Benda Sitaan Negara. Sumber Daya Perdesaan dan Kearifan Lokal, 7(6), 2017.

Pemasyarakatan, D. Bunga Rampai Pemasyarakatan: Kumpulan Tulisan Bahrudin Surjobroto. Jakarta, 2002.

Sugono, D. Kamus Besar Bahasa Indonesia. Jakarta: Pusat Bahasa. 2008.

Syaputra, Desman. "Penilaian Kinerja Karyawan Di Kantor RUPBASAN Kelas II Blitas Dengan Menggunakan Fuzzy Simple Additive Weighted." Journal of Information Technology and Computer Science Vol. 4, No. 2 , 2019.

Setyadi, Sigit. "Peran Rumah Penyimpanan Benda Sitaan Negara (Rupbasan) dalam Penegakan Hukum.” Jurnal Kajian Hukum Vol. 1, No. 2, 2016.

Wijaya, M. H. "Karakteristik Konsep Negara Hukum Pancasila". Jurnal Advokasi, Vol. 5, No. 2, 2015.

Republik Indonesia, Undang-Undang Dasar Negara Republik Indonesia Tahun 1945.

Undang-Undang Nomor 8 Tahun 1981 Tentang Hukum Acara Pidana. Lembaran Negara Tahun 1981 Nomor 76. Tambahan Lembaran Negara Nomor 3209.

, Undang-Undang Nomor 5 Tahun 2014 Tentang Aparatur Sipil

Negara. Lembaran Negara Tahun 2014 Nomor 6. Tambahan Lembaran Negara Nomor 5494.

Mahkamah Agung Republik Indonesia, Surat Edaran Ketua Mahkamah Agung Republik Indonesia Nomor 01 Tahun 2011 tentang Perubahan Surat 
Edaran Mahkamah Agung Nomor 2 Tahun 2010 tentang Penyampaian Salinan dan Petikan Putusan.

Kepolisian Republik Indonesia, Peraturan Bersama Kepala Kepolisian Republik Indonesia, Jaksa Agung, Komisi Pemberantasan Korupsi, Menteri Hukum dan Hak Asasi Manusia, Mahkamah Agung, Menteri Keuanagan Tentang Sinkronisasi Ketatalaksanaan Sistem Pengelolaan Benda Sitaan Negara dan Barang Rampasan Negara.

Badan Narkotika Nasional. "Data Statistik Kasus Narkoba" (https://puslit datin.bnn.go.id/portfolio/data-statistik-kasus-narkoba/) diakses pada 5 Januari 2020.

Direktorat Jenderal Pemasyarakatan. Sistem Database Pemasasyarakatan (smslap.ditjenpas.go.id), diakses pada 26 Maret 2019.

Ferdiyanto, R. "Barang Bukti di Rupbasan Nyaris jadi Rongsokan" (https://fokus.tempo.co/read/1039275/barang-bukti-di-rupbasan-nyaris jadi-rongsokan), diakses pada 17 Oktober 2019.

Jenderal Pemasyarakatan, D. "Laporan Tahunan Direktorat Jederal Pemasyarakatan Tahun 2017” (https://doi.org/10.17509/jrak.v5i2.7931) Jakarta: Direktorat Jenderal Pemasyarakatan, 2017.

Rima Wahyuningrum. "Motor-Motor Sitaan Negara di Rupbasan Masih Terpasang Kuncinya 2018" (https://megapolitan.kompas.com/read/ 2018/03/20/18302591/motor-motor-sitaan-negara-di-rupbasan-masih terpasang-kuncinya), diakses pada 5 Januari 2020.

Sistem Database Pemasyarakatan. (http://smslap.ditjenpas.go.id/public/rbs/cur rent/monthly), diakses pada 17 Oktober 2019. 